\title{
Konteks(te) waarbinne \\ apokaliptiese geskrifte gedurende die intertestamentêre periode floreer het
}

\author{
Marius Nel \\ Skool vir Bybelwetenskappe en Bybelse tale \\ Noordwes-Universiteit, Potchefstroomkampus
}

\begin{abstract}
Socio-economic context(s) within which apocalyptic texts flourished during the inter-testamentary period Social contexts form the perspective or symbolic framework of interpretation in which texts are to be read and understood because these texts originated within these contexts. An important question in the research into Jewish apocalyptic texts which originated in the period from $200 \mathrm{BCE}$ to $100 \mathrm{CE}$ is: What were the socio-economic context or contexts within which these texts originated and functioned? Various answers have been given: Apocalyptic has been viewed as the result of the wisdom tradition, of a pessimistic view of history, as a continuation and discontinuation with prophecy, as a reinstitution of myth in Hebrew thinking, as a result of orientation to a symbolic universe oriented to a supernatural world, and as a sociological matrix of alienation. Today many researchers agree that the origins of apocalyptic can only be described in terms of each apocalypse itself, in the light of Jewish experience during the Seleucid and Hasmonean periods.
\end{abstract}

\section{INLEIDING}

Die Daniëlboek se visioene (Dan 2:7-12) lui 'n Joodse belangstelling in apokaliptiek in wat die intertestamentêre periode kenmerk en ook in die Nuwe Testament neerslag vind (bv in Mark 13; Op). ${ }^{1}$ Die vraag ontstaan: Wat was die sosio-ekonomiese konteks of kontekste waarbinne dié tekste ontstaan en gefunksioneer het? Die vraag is belangrik omdat die sosio-ekonomiese konteks ' $n$ invloed op die ontstaan van nuwe denkrigtings uitoefen.

\footnotetext{
${ }^{1}$ Die teorie word hier aanvaar dat die Daniëlboek uit die tweede eeu vC dateer.
} 


\section{JOODSE APOKALIPTIEK}

\subsection{Waar kom apokaliptiek vandaan?}

Navorsers wat gepoog het om 'n haalbare werksdefinisie van apokaliptiek te verskaf, moes vervolgens die volgende vraag probeer beantwoord: waarin lê apokaliptiek se oorspronge? Is apokaliptiek 'n ongelukkige afdraaipad weg van die profete? Of is dit 'n lineêre ontwikkeling van die profete? Is dit 'n noodsaaklike en toepaslike ontwikkeling van profetiese visie? Wat onderskei profetiese en apokaliptiese eskatologie?

Hanson (1976:32) (asook Collins 2003:65) meld dat die onderskeidende faktor tussen profesie en apokaliptiek is of die toekomsvisie met die gebeure van die daaglikse lewe geïntegreer kan word, en of dit 'n radikale breuk met gewone geskiedenis benodig. ${ }^{2}$ Barker (1977-1978:325) stem nie saam nie. Sy meen Hanson restruktureer Bybelse gegewens as hy 'n onderskeid tussen profesie en apokaliptiek maak. Sy noem dat die rede hoekom normatiewe Judaïsme die Daniëlboek aanvaar het en ander apokaliptiese skrywers se werke verwerp het, juis was omdat apokaliptiese eskatologie by Daniël afwesig is. Barker definieer egter nie haar gebruik van "apokaliptiese eskatologie" nie. Sy bedoel waarskynlik daarmee 'n ontkenning van God se betrokkenheid by aardse geskiedenis.

Von Rad (1965:301) beweer dat nadat profesie ophou funksioneer het, Israel steeds na die toekoms gekyk en oor eskatologiese gebeure gespreek het. Israel het egter nou in 'n heel nuwe vorm gedink, wat met die term apokaliptiek aangedui kan word. Die rabbi's het volgens Seder Olam Rabba (Verhoef 1993:84) na die apokaliptiek verwys as die wettige voortsetting van die werk van die profete. ${ }^{3}$

\footnotetext{
${ }^{2}$ Verhoef (1993:83) gebruik die beeld dat profesie soos 'n vliegtuig is wat van die aanloopbaan van die geskiedenis vertrek en 'n eskatologiese toekoms binnevlieg, terwyl apokaliptiek 'n vliegtuig is wat deur die stormagtige wolke van die eskatologiese werklikheid verskyn om op die aanloopbaan van die hede te land. Die historiese situasie is vir die profesie van belang; die apokaliptiek kom van God se vertes af om te land in die situasie wat Hy self geskep het. Sien egter ook Charles (1963:174) wat die ooreenkomste tussen profesie en apokaliptiek vind in die kanale waardeur die openbaring of wil van God ontvang of gesoek word, die visioene (of transe) wat albei kenmerk, die staat van intense profetiese absorpsie, en allegorie wat vrylik gekonstrueerde en figuurlike beskrywings van werklike gebeure en persone is. ' $n$ Goeie voorbeeld van allegorie is Bunyan se "Pilgrim's progress". Aune (1983:41) noem dat die Siriërs veral bekend was vir hul profetiese kunste. So vertel Arrianus van 'n vrou wat Alexander die Grote gevolg het om hom met haar visioene en orakels te lei. Martha, ' $n$ ander Siriese profeet, het deur haar orakels aan die vrou van Marius, die Siriese regeerder vanaf 157 , vir alle praktiese doeleindes die adviseur van die Siriese regering geword.

${ }^{3}$ Vergelyk hierteenoor Rabbi Akiba wat volgens LaCocque (1988:84) sou gesê het dat enigeen wat die apokalipse lees, sy plek in die komende wêreld verbeur.
} 


\subsection{Wysheid en apokaliptiek}

LaCocque (2002:120) stem saam met Von Rad (1965:303) dat daar in 'n sekere sin geen verband tussen profesie en apokaliptiek bestaan nie, behalwe dat albei na die toekoms kyk. Die onversoenbaarheid tussen die twee lê in die onderskeie sieninge van die geskiedenis. Die verskil bestaan daarin dat die profetiese boodskap sy wortels in die heilsgeskiedenis van Israel vind, soos in die uitverkiesings- en uittogtradisies, terwyl die apokaliptiek geen melding van Israel se geskiedenis maak nie. Apokaliptiek vermeld nie die patriargetradisie, of die eksodus, of die Sionstradisie nie. Dié tradisies kry ook geen vermelding in die Daniëlboek nie. Die visioene in Daniël (2:6-12) dien as belangrikste teks binne die Ou Testament wat apokaliptiek promoveer. Slegs in die gebed van Daniël 9 word na die Onderwysing (Tora) van Moses en die uittog verwys, maar dit verteenwoordig 'n sekondêre interpolasie (Kratz 2002:104).

Von Rad (1965:303-305) se bekende gevolgtrekking is dat die enigste moontlike wortel waaruit apokaliptiek kon groei, die wysheidsgenre is. Die argumente wat hy hiervoor aanhaal, is:

- $\quad$ die titel van die beweerde skrywer bevat die benaming wyse man en nie profeet nie;

- $\quad$ om na die Daniëlboek te verwys, die voorspellings daaarin vloei nie uit 'n profetiese impuls nie, maar uit die interpretasie van drome;

- die intensie van die boek is nie om deel te neem aan sosiale en politieke konflikte nie, maar om die geskiedenis in 'n bynadeterministiese toonaard te beskryf.

Die outeur kan dus nie as opvolger van die profete beskou word nie. ${ }^{4}$ Koch (1987:240) se besware hierteen is egter geldig: die wysheidsliteratuur toon geen vorm-kritiese parallelle met die Daniëlboek nie, en daar is geen teken van 'n belangstelling in die eskatologie in enige wysheidsliteratuur wat uit die tweede eeu bewaar gebly het nie (soos bv in die Wysheid van Jesus Ben Sirag gesien kan word).

\footnotetext{
${ }^{4}$ Soggin (1984:291-292) stem saam. Apokaliptiek het iets in gemeen met die profete: beide deel geloof in die God van Israel as die Here van geskiedenis. Hy sal die geskiedenis tot 'n einde bring deur dit te vervul. Daar is egter soveel verskille tussen apokaliptiek en profesie dat apokaliptiek hoogstens as 'n "bastard child" van profesie beskou kan word. Die verskille sien Soggin daarin dat apokaliptiek se boodskap 'n geheim is, wat aan iemand toevertrou word wat dit moet bewaar en aan die einde van tyd moet openbaar. Hy beskou verkeerdelik wat 'n literêre tegniek is om 'n boodskap as geheimnisvol te beskryf, as die werklikheid waarin die boek geskryf is. Die apokaliptikus is ook nie 'n prediker nie, maar eerder 'n wysheidsleraar, volgens Soggin.
} 


\section{Konteks(te) waarbinne apokaliptiese geskrifte floreer het}

Von Rad is reg as hy op die verband tussen wysheid en apokaliptiek wys, maar hy verloor uit die oog dat apokaliptiek in profesie sy ander pa vind (Baldwin 1978:50; DiTomasso 2005:6). ${ }^{5}$

Dit beteken nie dat daar geen verband tussen wysheid en apokaliptiek bestaan nie. ${ }^{6}$ Die skrywer is deurdrenk van die wysheids- sowel as profetiese literatuur van sy wêreld, en kan nie anders as om dit in sy werk en denke te verdiskonteer nie. "It is my tentative judgment that wisdom was wedded to the tradition of apocalyptic eschatology as a part of efforts being made by visionary circles to establish their credentials in the third and second century $\mathrm{BC}$ at a time when prophetic figures were being regarded with a great deal of scepticism and even animosity by many religious leaders" (Hanson 1979:9).

\subsection{Geskiedenisbeeld}

Vorster (1986:160) en Brueggemann (1997:514) stem saam: apokaliptiek vind sy ontstaan in 'n radikale breuk met hoe na die hede en verlede gekyk is, in 'n reïnterpretasie daarvan in die lig van 'n nuwe toekoms. Dit word gekenmerk deur radikale pessimisme, waar alle menslike ingryping gelikwideer is, en daar slegs gewag word op die utopie met sy nuwe simboliese samehang. Die wêreldgeskiedenis is besig om oor die afgrond te stort, wat as oorsaak die natuur van die mens, en die ryke wat deur hom tot stand gebring word het.

Die belangrikste vraag wat die onderdrukking deur vreemde oorheersers aan die Jood stel, is die teodiseeprobleem: Wie is in beheer van die geskiedenis? Die gode van die nasies, of die God van Israel? Is die gelowige slagoffer van 'n blinde noodlot, of speelbal van die gode, of kinders van 'n liefdevolle God wat met hom op pad is? Is God se mag slegs tot Palestina beperk, as die onmiddellike invloedsfeer van Sion? Of heers God ook in Babel, en tussen die verarmde en onderdrukte agtergeblewenes in die beloofde land?

Nog 'n kenmerk van dié pessimistiese geskiedenisbeeld is dat daar geen verwagting van redding in die hede voorkom nie. Die hele reddingsaktiwiteit waarna uitgesien word, is eskatologies en toekomstig, en daar kom geen belydeniskarakter voor nie, sê Von Rad (1965:303). Apokaliptiese literatuur praat van goed en kwaad asof dit tydloos is. Apokaliptiese literatuur het slegs belang by die laaste geslag van Israel, dié wat, soos geglo is, op die punt staan om die einde van die tye tegemoet te gaan.

\footnotetext{
${ }^{5}$ Vergelyk ook Von der Osten-Sacken (1969:60) se argument dat dit mag wees dat beide apokaliptisisme en die laat vorme van wysheid in Juda van die profete se visioen van God as beide Here van die geskiedenis en Skepper van die natuur afhanklik is.

${ }^{6}$ Die Talmoed beskryf Daniël se wysheid as so groot dat dit die wysheid van die wyses van alle volke oortref. As al die wyses van die wêreld op een kant van die skaal geplaas word, sal Daniël aan die ander kant swaarder weeg (Brockhaus s a:12). Die Daniëlboek stel hom ook immers so voor - tien maal slimmer as die Babiloniese wyses.
} 
In die Daniëlboek word 'n breë prentjie van die wêreldgeskiedenis geskets, waar telkens 'n oorsig oor koninkryke en hul invloedsfeer gegee word. Daar word wel bemoeienis met geskiedenis gemaak. Maar die geskiedenis word deterministies voorgestel, asof mense slagoffer is van besluite wat reeds lank tevore geneem is, en waarin hulle geen sê het nie.

Ek meen dat ' $n$ mens hier die paradoksale wyse waarop die boek met determinisme en 'n geskiedenisbeeld te werk gaan, in gedagte moet hou wanneer oor die konteks(te) waarbinne apokaliptiek ontstaan gefunksioneer het, gespekuleer word. Die determinisme dien as 'n vertroosting vir die gelowige - asof alles deur God vasgestel is. Die situasie van verdrukking en vervolging deur vreemde oorheersers was kritiek. Dit is nie in die eerste plek 'n element van die skrywer se geskiedenisideologie nie. So word allegoriese kodes gebruik om die hele historiese proses onder 'n paar noemers saam te vat en konseptueel te objektifeer. En die geskiedenis word geskematiseer en verenig deurdat dit geskiedenis reduseer tot enkele primêre magte wat daarin werksaam sou wees. Die mens is slegs in beperkte mate agent in wat plaasvind. Hy het min mag van keuse. Porteous (1979:184) en Collins (2004:283) wil dié determinisme reeds in die profeteboeke gaan soek, in hulle sekerheid dat JHWH die Here van die geskiedenis is, en dat sy wil altyd geskied.

Waar die profete regop gaan staan en duidelik hulle standpunt gestel het, dikwels téén die heersende politieke sentiment, is die skrywer van die apokaliptiek 'n onbekende figuur (of kring, soos sommige beweer - die Chasidim of Maskilim), wat 'n boodskap in verhulde vorm en sonder politieke ondertone bring. Hy dra die boodskap oor: die wêreldgeskiedenis toon dat alle epogge vooraf bepaal is. Sommige meen dat die skrywer van die Daniëlboek gekant is teen enige politieke aktivisme - hy staan by dié wat lyding verdra eerder as die wapen opneem. ${ }^{7}$ Die Makkabeërs se oorwinnings sou dan, volgens Daniël 11:34, vir hom onbelangrik wees. ${ }^{8}$

\footnotetext{
${ }^{7}$ Venter (1997:78) haal navorsing aan wat verskillende groepe of sektes binne die Chasidim identifiseer. Hy bespreek twee standpunte. Sommige navorsers meen die Daniëlboek met sy rewolusionistiese mentaliteit staan teenoor 'n utopiese Henogboek. Hierteenoor staan die mening dat die groepe waaruit Henog en Daniël ontstaan, onderskeie Chasidiese sektes is wat vir lank teen mekaar gestry het maar nou in reaksie op Antiochus IV se beleid saamwerk. Venter (1997:79) is van opinie dat die ponering van 'n pasifistiese en militaristiese groep, met die Henog- en Daniëlboek wat aan 'n groep toegeken word, nie reg aan beskikbare data laat geskied nie. Groot onsekerheid bestaan in elk geval oor die gebruik van die term "Chasidim." Verwys dit na 'n groep wat getrou aan die Tora gebly het, of na 'n groep skrywers of priesters wat leierskap in die rebellie asook die apokaliptiese literatuur verskaf het?

${ }^{8}$ Vergelyk Stahl (1994:23) se opmerking dat die Makkabeëropstand voor alles 'n burgeroorlog was, wat Jood teen Jood te staan gebring het. Dit was 'n stryd tussen "den Gesetzetreuen und Abtrünnigen." Slegs die anti-Helleniste is in stryd met die vervolger, en slegs hulle is "die heiliges." Pro-Hellenistiese groepe word van die toekomstige koninkryk uitgesluit (Joubert 1979:135).
} 


\section{Konteks(te) waarbinne apokaliptiese geskrifte floreer het}

As van apokaliptiese literatuur in die Daniëlboek gepraat word, sluit dit slegs die visioene in. Navorsers tel Daniël 2 gewoonlik saam met hoofstukke 7-12, en ondersoek na vormkritiese ooreenkomste bevestig dit. Die samesteller van die boek het 'n aanpassing gemaak toe hy dié verhaal oorvertel het. In ooreenstemming met die gegewens wat die visioene bevat, skryf hy 'n vyfde ryk in die droom in. Dié ryk het 'n tipiese apokaliptiese trek as dit 'n einde aan die wêreldgeskiedenis maak. Die klip, wat die vyfde ryk voorstel, vernietig die beeld.

\subsection{Wysheidsliteratuur}

Die hofverhale (Dan 1-6) is duidelik deel van die wysheidsliteratuur. Die wysheidsliteratuur was die produk van wysgere van die Ou Testament wat mense wou help om die samehang of die orde van God in die skepping raak te sien, en daarvolgens te lewe. Hulle druk hul ervarings, opmerkings en raad uit in spreuke en spreekwoorde (soos in Spreuke), beredenerings (soos in Prediker), hofverhale (soos in Ester en Daniël) en liedere (soos in sommige Psalms - Burden 1987:198-199). Porteous (1979:184) volg Collins in 'n onderskeiding tussen "proverbial wisdom" wat die wysheidsliteratuur van die Ou Testament kenmerk, en mantiese wysheid wat in die apokaliptiese literatuur voorkom. ${ }^{9}$

Die Babiloniese koning moet die bepalings van die Joodse Tora gehoorsaam as hy in harmonie met die goddelike orde wil wees. Nebukadnesar bely dit, en kry in die vierde hoofstuk 'n tweede kans, terwyl Belsasar se lot vooraf bepaal is, en hy ten spyte van sy belydenis sterf. Het dit te doen met sy misbruik van JHWH se tempelvoorwerpe, of is dit 'n aanduiding van die determinisme wat die visioene kenmerk ${ }^{10}$

Opsommend, Von Rad (1965:306) meen dat kennis of wysheid (gogma) die senusentrum van alle apokaliptiese literatuur is. Dit is gebaseer op 'n universele Jahwisme en geskei van die heilsgeskiedenis van Israel. Dit is die matriks waaruit die apokaliptiek groei, meen hy. Dit beteken dat die apokaliptiese literatuur tussen die Wysheidsboeke geplaas behoort te word,

\footnotetext{
${ }^{9}$ Collins (1977:85) verwys na 'n dokument wat aan Diodorus Siculus (2.30) toegeskryf word waarin hy die volgende oor die mantiese wysheid van die Chaldeërs kwyt raak: "Die Chaldeërs sê dat die aard van die wêreld ewig is, en dat die orde en rangskikking van die geheel deur 'n goddelike voorsienigheid gewaarborg is, dat die individuele dinge in die hemel voltooi is, nie deur die lot nie maar deur 'n sekere bepaalde en gesette oordeel van die gode. Deur waarnemings van die sterre oor ' $n$ lang periode te maak, voorspel hulle talle van die dinge wat sal kom (my vertaling)." Die term wat die Grieke die meeste gebruik vir die beoefenaar van toekomsvoorspelling is mantis, wat soms met "profeet" vertaal word. Die belangrikheid om goddelike boodskappe wat dikwels komplekse simboliek bevat en hoogs verwarrend kan wees, te dekodeer, het tot 'n hoë waardering van die kunste van die mantis gelei.
}

${ }^{10}$ Daniël 4:14, 17 en 22 kom baie naby aan determinisme (LaCocque 1988:98). 
soos die Hebreeuse kanon trouens doen. In die wysheidsliteratuur wil die mense van Israel (in gemeen met talle ander volke) die wette probeer verstaan wat die wêreld waarin hul leef, beheers. Dié wette moet gesistematiseer word sodat die mens sy lewe daarvolgens kan inrig en hieruit ontwikkel 'n ensiklopediese wetenskap. Vir dié rede word Daniël geskets as dat hy as 'n wyse man opgelei is. Apokaliptici is navorsers en geleerdes wat die wetenskap van hul dag onder die knie het. Daniël is Josef redivivus.

In die wysheidsliteratuur gaan dit ook om wette, maar nie meer oor die Tora nie. Van wette word op 'n absolute manier gepraat, as alles-bevattend en met 'n betekenis wat vir alle tye geldig is. ${ }^{11}$

\subsection{Diskontinuïteit tussen profesie en apokaliptiek}

Moltmann $(1967: 124,126)$ maak die belangrike punt dat die hele Ou Testament eskatologies is omdat dit vooruit gekyk het na die vervulling van groter en beter beloftes. As Moltmann reg is, beteken dit dat apokaliptiek op dieselfde vlak bestaan as die res van die Ou Testament. Moltmann (1967:132) beskryf dit as 'n kenmerk van eskatologiese profesie dat dit weier om hoop in God te verloor, in die lig van sy oordele. Profesie projekteer eerder daardie hoop buite die eindelike grense van bestaan. Hieruit ontstaan die gevolgtrekking dat apokaliptiek direk in die profetiese tradisie staan: “... in apocalyptic the whole cosmos becomes interpreted in the light of truth learned from God's revelation in Israel's history" (Moltmann 1967:137). Apokaliptiek is die wettige voortsetting van profesie. Dit beteken dat apokaliptici se visioen korrek is: die hele geskiedenis staan onder God se "nee." Die enigste hoop is in 'n toekoms van God wat radikaal met die huidige werklikheid breek (Collins 2004:553).

Alhoewel saamgestem word dat profesie en apokaliptiek dieselfde beginpunt en belang het, bestaan daar tog belangrike diskontinuïteite. Daar verskyn drie sintetiese studies in die sewentigerjare wat op die diskontinuïteite klem lê. Koch (1972:130) bevind dat die maklike verbintenis tussen profesie en apokaliptiek nie stand hou nie. Morris $(1972: 31,34,42,60,63)$ dui puntvir-punt onderskeidinge aan wat tussen profesie en apokaliptiek bestaan. Schmithals (1975:73-77) toon eers die ooreenkomste aan:

\footnotetext{
${ }^{11}$ Cantor (1994:16) se standpunt is dat alle Joodse geskiedenis vanaf die tweede eeu onthistoriseer is, ook die Tora, ter wille van Joodse idealisering van hul wortels. En die rede? "The later Maccabees were not moral paragons, and the redacting rabbis apparently thought the history of this late Jewish royal dynasty should fade out with an account only of its earlier, more positive era - the one celebrated in the festival of Hanukkah" (Cantor 1994:13). Daarom het Daniël dit in die kanon gemaak om toegelaat te word, sê Cantor, maar nie die Makkabeërboeke nie.
} 


\section{Konteks(te) waarbinne apokaliptiese geskrifte floreer het}

- $\quad$ profesie en apokaliptiek deel 'n begrip van bestaan - dit is histories van aard;

- $\quad$ dit deel dieselfde konsep van God - Hy is Here van die geskiedenis;

- $\quad$ profesie en apokaliptiek deel ook dieselfde beeld van die mensdom dit is 'n historiese moontlikheid;

- $\quad$ en dit deel dieselfde konseptualisering van tyd - van liniêre progressie na 'n doel.

Tog is die onderskeidinge tussen profesie en apokaliptiek groter. Die apokaliptikus sien homself in 'n radikale breuk met wat vooraf gegaan het. Hy bring 'n radikaal nuwe openbaring. Hy is radikaal pessimisties oor die huidige era en voorsien nie dat die huidige wêreld gereinig en vernuwe kan word nie. Daar is ook geen historiese heil nie. Historiese aktiwiteit word beperk en vervang deur kennis oor die betekenis en uitkoms van historiese gebeure (Schmithals 1975:80-82). "Apocalyptic thinks historically in principle, ... but it despairs of history itself ... in the apocalypticist's conviction that he stands at the end of history there is expressed therefore the hopeful, joyous assurance that history is coming to its end - an attitude utterly impossible for the Old Testament" (Schmithals 1975:88).

Oswalt (1999:376) meen Schmithals laat dit lyk asof die Ou Testament niks weet van heil verby historiese heil nie. En hy impliseer dat apokaliptiek 'n verval is, 'n agteruitgang van die insigte wat profesie gebring het. Weer eens bied die beskrywings nie genoeg lig om die verskynsel van apokaliptiek te verklaar nie.

\subsection{F M Cross en P D Hanson}

Cross (1966:11-30) bespreek ook die oorgang van profetiese na apokaliptiese eskatologie. Hy meen dat dit eskatologiese profesie se herinvoering van mite in die hoofstroom Hebreeuse denke is wat die weg vir apokaliptiese visie voorberei het. Die eksiliese en post-eksiliese profete eien die skeppingsmites asook die mite van die Goddelike Vegter toe as heil in die geskiedenis nie realiseer nie. Die mites was latent maar onderdruk in Israel. So plaas die profete hul hoop vanaf die teleurstellende historiese vlak na die kosmiese vlak. Die profete het geweet dat niemand hul profesieë as vals kan bewys as dit op die kosmiese vlak funksioneer nie. Hul profetiese uitsprake kon nie weer teleur stel nie. ${ }^{12}$

Die bekendste student van Cross in die Verenigde State van Amerika is Hanson. Hanson (1979:11) stel voor dat die oorsprong van apokaliptiek in

\footnotetext{
${ }^{12}$ Vergelyk ook Cross (1973:344-346) en Carroll (1979:215-218).
} 
die onmiddellike post-eksiliese gemeenskap soos verteenwoordig deur Tritojesaja, Haggai en Sagaria, gesoek moet word. Die rede vir die oorsprong kom in Deuterojesaja se eskatologiese visie voor wat mitologiese motiewe in sy geskrif gebruik. Sy volgelinge staan die herbouing van die Tweede Tempel wat Esegiël se volgelinge deurvoer, teen. Die realiste word magtiger as die tempel in gebruik geneem word. Die visioenêre, wat die dissipels van Deuterojesaja se idees is, onttrek hulle al meer in apokaliptiese hoop. Esra en Kronieke se boeke verhaal dat die visioenêre as 'n groep mettertyd uitsterf. In die donker dae van die Seleukiede en Hasmoneërs word die visioenêre se geskrifte herontdek en nuut toegepas. ${ }^{13}$

Die ineenstorting rondom die ballingskap lei tot twee groeperings: die een groep wil terugkeer na die instellings en gebruike voor die ballingskap, en die marginale groep laat val die klem op die nuwe koninkryk ten koste van die ou tradisies. Die eerste groep is werklikheidsgebonde en realisties asook pragmaties, terwyl die tweede groep idealisties en visioenêr is (Vorster 1986:161). Die eerste groep, die hiërokrate, is die afstammelinge van die Sadokitiese priesterhuis, wat voor die ballingskap die tempel en kultus oorheers, en wat nou (o a in Esegiël 40-48) 'n program van herstel vir die koningshuis en tempel voorstel. Hulle geniet ook die steun van die Persiese oorheersers. Vir hulle tree $\mathrm{JHWH}$ in die geskiedenis op. ${ }^{14}$

Hierteenoor ontstaan 'n apokaliptiese beweging in die laaste deel van die sesde en die vyfde eeu, wat aanleiding gee tot Jesaja 24-27, 56-66, die Maleagiboek en Sagaria 9-14. Die visioenêre sekteleiers neem hul toevlug tot 'n simboliese universum wat aan die bonatuurlike wêreld georiënteer is. Verlossing en oordeel is redding uit die geskiedenis, en nie langer meer in die geskiedenis nie. Dit vorm die agtergrond, sê Vorster (1986:163), vir die

\footnotetext{
${ }^{13}$ Millar (1976) is ook 'n student van Cross. In sy ondersoek na Jesaja 24-27 kom hy tot effe ander gevolgtrekkings. Hy maak nie soveel van die sosiologiese konflik wat Hanson meen hy daarin ontdek nie. Hy meen die hoofstukke kom uit die periode direk ná die ballingskap en gebruik mitologiese temas in reaksie op die krisis van die tyd.

${ }^{14}$ Burden (1987:217) verwys na vier groepe wat in die tweede eeu 'n rol speel en invloed uitoefen: die priesters met hul kultiese benadering; profestiese eskatologie wat deur die tradisionele profete verkondig is; apokaliptiese eskatologie wat die boodskap van die radikale visioenêres is; en 'n filosofiese groep wat in die wysheidskole bestaan. Volgens hom groei die Selote, Sadduseërs, Fariseërs en Herodiane van Nuwe Testamentiese tye uit die konflik en amalgamasie van dié groepe. LaCocque (1988:123) haal die werk van die Duitse Joodse geleerde, Abraham Geiger, van 1857 aan wat in die finale vorm van die Daniëlteks 'n reflektering van die konflik tussen die Fariseërs en Sadduseërs sien, ten tye van die Tweede Tempel (die Jode noem die periode vanaf $516 \mathrm{vC}$ tot $70 \mathrm{nC}$ so). Dit is legalistiese Fariseïsme wat mettertyd die apokaliptiese element uitdryf, volgens Charles (1963:196), en die vader van Talmoediese Judaïsme word. Apokaliptiese Judaïsme sien volgens hom mettertyd raak dat die Tora nie in staat is om die volk tot redding te lei nie, en voeg dan die leerstelling van geloof deur die genade van God by. In dié sin is apokaliptiek die vader van die Christelike geloof. Daar kom geen vermelding van of verwysing na die Tora in enige Nuwe Testamentiese apokalips voor nie.
} 


\section{Konteks(te) waarbinne apokaliptiese geskrifte floreer het}

verstaan van apokaliptiese tekste: vanuit die verwagting van 'n nuwe eeu en 'n nuwe wêreld word hede, verlede en toekoms geïnterpreteer en beleef.

Die element van realisme, wat die hiërokrate kenmerk, is besig met die daaglikse onderhoud van strukture en instellings, om die gemeenskap te onderhou ter wille van 'n kontinue bestaan van die gemeenskap. Die visioenêre element gebruik as visie dié van 'n goddelike orde wat alle alledaagse instellings en strukture transendeer, en dit onder oordeel plaas om daardeur te weier om deel daarvan te word. In die spanningsveld tussen realistiese en visoenêre, tussen profeet en apokaliptikus, vind Hanson (1979:30) die daeraad van apokaliptiek.

Hanson (1979:7-8), met sy kontekstueel-tipologiese benadering, is van mening dat die opkoms van apokaliptiese eskatologie nie skielik of afwykend was nie, maar die patroon van ononderbroke ontwikkeling van pre-eksiliese en eksiliese profesie gevolg het. Invloede van buite (bv Persiese dualisme, Iranese mitologie of Hellenisme) het láát ingewerk, eers nadat die essensiële karakter van apokaliptiese eskatologie reeds tot volle vrug gegroei het. En die invloede is beperk juis vanweë hul periferale aard. ${ }^{15}$

Een van die belangrikste bydraes van vormkritiese ondersoek was dat vorme vanuit 'n Sitz im Leben funksioneer. Dit is slegs onlangs dat Bybelse eksegete dié kwessie ernstig begin neem het. Ook apokalipse is aan sosiologiese analise onderwerp. Hanson se bydrae staan bo almal uit. Terwyl profete hul visioenêre konsepte met die werklikheid kombineer, slaag apokaliptiese literatuur nie daarin om hul visioene en boodskap van God se plan in terme van geskiedenis en politiek te vertaal nie. Hanson (1979:32) delinieer die sosiologiese matriks van vervreemding as die konteks waarbinne die verandering in die eskatologiese uitkyk plaasgevind het. Die politieke, ekonomiese en godsdienstige ommekeer het 'n klimaat geskep wat aanleidend was tot die ontstaan van apokaliptiese bewegings. Dit impliseer wat die voorwaarde is vir die ontstaan van soortgelyke bewegings in ons dag.

Hanson gebruik Karl Mannheim se sosiologiese model van kennis om twee mentaliteite in post-eksiliese Judaïsme te kontrasteer: 'n ideologiese en utopiese. ${ }^{16}$ Die ideologiese groep verteenwoordig die heersers en beskerm en handhaaf die status quo omdat dit die strukture verteenwoordig wat aan hulle 'n posisie van mag verleen. Die utopiese groep verteenwoordig die verdruktes en soek na verandering deur die status quo te ondermyn en te vernietig.

\footnotetext{
${ }^{15}$ Die Persiese godsdiens beïnvloed volgens Enslin (1971:1107) die Joodse omdat albei een Oppergod aanbid, beide afgodery bitterlik gehaat het, en albei na 'n komende heerlike eeu soek. Die beïnvloeding was volgens hom verseker slegs deur onbewuste stimulasie.

${ }^{16}$ Brueggemann (1983:321) kritiseer Hanson as dat hy te skematies te werk gaan as hy die post-eksiliese literatuur organiseer.
} 
Hanson neem die konsep van Max Weber oor dat profetisme 'n oproep tot 'n breuk met die status quo verteenwoordig, terwyl die priesterskap gewoonlik met die strukture van die "establishment" verbind word. Die verdruktes is diegene wat hulself met die profetiese godsdiens identifiseer, of in lyn daarmee dink (Hanson 1979:213-214). Hanson meen die hiërokratiese party word deur die Sadokiete gelei wat belang het by die handhawing van mag. Die visioenêre bestaan uit die Leviete as kern, wat van die maghebbers vervreem geraak het toe hulle uit die institusionele magstrukture gegooi is. Dit is hulle wat wag dat JHWH die bestaande orde omverwerp, waaruit apokaliptiese eskatologie groei (Le Roux 1988:16).

Hanson (1995:9-10) vind drie primêre faktore wat verantwoordelik is vir die ontwikkeling van apokaliptiese eskatologie uit sy vroeëre profetiese wortels:

- $\quad$ die self-identifisering van die protagoniste van apokaliptiek met die klassieke profetiese tradisie;

- $\quad$ die gebruik van koninklike en mitopoïese ${ }^{17}$ materiaal, met 'n letterlikheid in die interpretasie daarvan wat van Deuterojesaja verskil koninklike teologie eis dat Sion onweerlegbaar en Dawid se dinastie ewig is;

- $\quad$ en die konteks van 'n post-eksiliese Joodse gemeenskap wat deur krisisse bedreig word en stoei om by hul nuwe status aan te pas. Die Joodse gemeenskap ly onder die gebrek aan eenheid in die gemeenskap, waaruit uiteindelik 'n visioenêre en hiërokratiese gemeenskap groei.

Hanson (1995:11) definieer profetiese eskatologie as 'n religieuse perspektief wat op die profetiese aankondiging aan die nasie van JHWH se planne vir Israel en die wêreld fokus. Die profeet se rol is om sy getuienis oor die goddelike raad te vertaal in terme van gewone geskiedenis, werklike politiek en menslike instrumentaliteit in God se hand. Dit beteken dat die profeet aan die koning en volk verduidelik hoe JHWH se planne in die konteks van hul volk se geskiedenis en dié van die wêreld sal realiseer. Dit is dan ook die unieke belang van die profete. Hulle was verantwoordelik daarvoor om Israel se godsdiens te historiseer en sy geskiedenis te teologiseer. Hulle het die kosmiese visie in die geskiedenis geïntegreer en die mite verruil vir 'n meer

\footnotetext{
${ }^{17}$ Hanson (1995:24) definieer 'n mitopoeïese wêreldbeeld as "that Yahweh acts through historical events and persons to save his people."
} 


\section{Konteks(te) waarbinne apokaliptiese geskrifte floreer het}

gesekulariseerde, humanistiese wêreldbeeld. Apokaliptiese eskatologie, daarenteen, is die religieuse perspektief wat op die bekendmaking (wat dikwels esoteries van aard is) aan 'n klein handjievol van uitverkorenes fokus om die kosmiese visie van JHWH se soewereiniteit, spesifiek daarin geleë om die getroues se lewe te red, aan te kondig. Die visioenêres vertaal dit nie meer in terme van gewone geskiedenis, werklike politiek en menslike instrumentaliteit nie, omdat 'n pessimistiese siening van die werklikheid die post-eksiliese apokaliptiese gemeenskap oorheers. Daniël mag sy boodskap verseël omdat dit nie nodig is om die twee sfere, die kosmiese en alledaagse, te versoen nie (Dan 12:4).

Hierin lê die essensiële verskil tussen die profetiese en apokaliptiese eskatologie. Die profeet beskou die geskiedenis as die konteks van goddelike aktiwiteit. Dit is sy taak om die visie van goddelike aktiwiteit van die kosmiese vlak na die vlak van polities-historiese lewe op aarde te vertaal. Die visioenêr is ontnugter met die historiese werklikheid, en sy visie word al meer losgemaak van die politieke en historiese sfeer. Sy taal bly in dié van die kosmiese sfeer van die Goddelike Vegter en sy raad vasgevang.

Die pessimisme van die visioenêr, in teenstelling met die optimisme van die profeet, kan dan ook verklaar word uit die verskuiwing wat tussen profetiese en apokaliptiese eskatologie plaasgevind het. Die profeet glo dat die visie van JHWH se herstel van sy volk binne die historiese milieu gaan plaasvind. Die visioenêre dissipels van die profeet dien nie meer as amptenare van die politieke bestel nie, omdat hulle volk alle politieke strukture deur vreemde oorheersers ontsê is. "Tending to respiritualize Yahwism by leaving their vision more on the cosmic level of the activities of the Divine Warrior and his council, they increasingly abdicated the responsibility to the politico-historical order of translating the cosmic vision into the terms of the mundane" (Hanson 1979:26). Die rede hiervoor is dat die polities-historiese sfeer as boos beskou word, 'n sfeer waaroor hulle nie meer beheer het nie, soos deur hul omstandighede as post-eksiliese gemeenskap aangetoon. Deur die vervulling nie meer aan die historiese gebeure te koppel nie maar aan die kosmiese sfeer van mite, word 'n ontsnappingsroete uit die groeiende weerspreking tussen die wonderlike belofte en die harde werklikheid gevind.

Die basiese kontinuïteit tussen profesie en apokaliptiek bestaan in die visie van JHWH se volk, as 'n herstelde en heilige gemeenskap in ' $n$ verheerlikte Sion. "It is this basic continuity which compels us to speak of one unbroken strand extending throughout the history of prophetic and apocalyptic eschatology" (Hanson 1979:12).

Nadat die Daniëlboek voltooi is, het die genre minder suiwer geword, met elemente wat deur ortodoksie as verdag beskou is. So word dit 
byvoorbeeld gekenmerk deur ontologiese dualisme. Vir dié rede is Daniël as deel van die kanon aanvaar, terwyl die apokriewe en pseudonieme apokaliptiese literatuur uitgelaat is.

\subsection{Besware teen Hanson}

Hanson toon aan dat eskatologiese en apokaliptiese visies nie onversoenbaar is nie. Tog funksioneer hy (en die skool wat deur hom verteenwoordig word) met sekere veronderstellings wat aanvegbaar is. Hy beklemtoon die latere profete se gebruik van mitologiese bronne, wat moontlik niks meer as beeldende gebruik van analogieë is nie. So word die beeld van die goddelike vegter myns insiens ongegrond gebruik. Alle navorsers aanvaar nie Hanson se literêre en sosiologiese ontwikkelingstipologieë nie. Sy teorie is afhanklik van 'n hipotetiese rekonstruksie van Juda se samelewing en geskiedenis. Hy kan nie veel historiese gegewens aanbied om die rekonstruksie te verdedig nie. $^{18}$

Hanson se werk berus op die luns dat die latere profete van mitologiese motiewe afhanklik is om die konsep van God, wat nóú aan die geskiedenis verbind is, uit te brei. Die nuwe konsep van God en sy aktiwiteit buite die geskiedenis, wat deur die latere profete geskep word, vorm die antihistoriese basis van apokaliptiese werke. Dit is egter nie moontlik om na laatprofetiese tekste te verwys wat verseker na God se aktiwiteit buite die geskiedenis om verwys nie. Die enkele mitologiese verwysings veronderstel 'n historiese basis, deurdat die mitologiese verwysing slegs na 'n assosiasie verwys, wat deur die profeet geherinterpreteer word. Die betekenis van die beelde lê in Israel se geskiedenis. "There is thus ample reason to assume that these accounts are being used in a literary way and not in any sense as an affirmation of their value as a way of thinking" (Oswalt 1999:380). Dit lei Oswalt (1999:383) tot die gevolgtrekking dat die gebruik van mitologiese motiewe nie Hebreeuse denke sterk beïnvloed het nie, en dat laat-profesie nie

\footnotetext{
${ }^{18} \mathrm{Nie}$ almal stem hiermee saam nie. Ten spyte van kritiek op die werk van Hanson meen Le Roux (1988:22) Hanson vat raak as hy klem plaas op die invloed wat die val van Jerusalem op die ontwikkeling van eskatologie uitgeoefen het - op hoe die wêreld gesien word en op hoe profesie geag word. Heil word al verder en verder die toekoms ingeskuif. Hanson plaas ook klem op die verband tussen eskatologie en die sosiale konteks, en praat van verskillende tipes eskatologie wat verband hou met verskillende sosiale kontekste. Die sosiale konteks vorm volgens Hanson die perspektief of simboliese interpretasieraamwerk waarbinne die tekste gelees en verstaan moet word, omdat dit binne dié kontekste ontstaan het. Moderne belangstelling in apokaliptiek, en die geboorte van hedendaagse apokaliptiese bewegings soos Hare Krishna en Process, kan steeds toegeskryf word aan die polarisering van die realistiese en visioenêre elemente van godsdiens. Trouens, die eietydse onrus in ons samelewing kan ook beskryf word in terme van die botsing tussen visioenêre jongmense en hul realistiese ouers en voorgangers. In dié gebeure, soos deur alle eeue, sal die aktiwiteit van die profetiese figuur wat die lewende kreatiewe spanning tussen visie en werklikheid behou, die hart van egte godsdiens wees (Hanson 1979:31).
} 


\section{Konteks(te) waarbinne apokaliptiese geskrifte floreer het}

deur die gebruik van die mitologiese motiewe die a-historiese klimaat vir apokaliptiek geskep het nie.

Hanson se kontekstueel-tipologiese metode is op prosodiese analise gebaseer wat 'n ewolusionêre patroon van sosiale konflik voorstel. ${ }^{19}$ Dit stel die skrywer in staat om die verskillende dele van die werk van post-eksiliese profete in die korrekte volgorde te plaas. Hanson se beskrywing van die korrekte orde verskil nie net van die kanoniese orde nie, maar ook van die voorstelle van ander navorsers. Dit stel vrae oor die betroubaarheid van die metode.

Dit is opvallend dat die twee groepe wat Hanson voorstel (die priesterlike realiste en anti-institusionele visioenêre) analoog is aan die groeperinge van die sestigerjare, as Hanson sy navorsing doen. Dit is ook 'n geldige vraag of dit toelaatbaar is om Max Weber en Karl Mannheim se programmatiese sienings van klassestryd na die Midde-Ooste van twee en 'n half millenia gelede in te voer. Die gevolg is moontlik dat geskiedenis op Procrustus se bed gerek word om sosiologiese teorie te pas. Rowland (1982:196) som die argument op:

Nevertheless, it would be wrong to suppose that, by recovering the resurgence of certain myths in the eschatology of the visionary group which produced some of the oracles of Third Isaiah, one has necessarily uncovered the essential ingredient in apocalyptic, or even, for that matter, in apocalyptic eschatology.

Rowland is onseker of ' $n$ beweging gerig tot redding deur God in een of ander bonatuurlike sfeer werklik die sleutel tot apokaliptiek vorm.

Ook Hanson se verduideliking hoe profesie tot apokaliptiek gegroei het, slaag nie in alle opsigte nie. Dat daar 'n verbintenis tussen profesie en apokaliptiek bestaan, betwyfel min. Die navorser sukkel egter om die verbintenis te beskryf, omdat die apokalipse so kompleks is en moderne kennis van apokalipse se ontstaan en skeppers so skraps is. Tussen 425 en $175 \mathrm{vC}$ het sekere kritieke elemente profesie op weë gelei wat apokalips uiteindelik buite die beperkinge van Ou Testamentiese geloof gevoer het.

\section{$2.8 \quad J \mathrm{~J}$ Collins}

Sedert 1980 het navorsers al meer begin saamstem dat apokaliptiek nie 'n enkele dominante voorouer het nie. Die oorsprong moet eerder in 'n kompleks van faktore gesoek word. En die navorser kan 'n beskrywing van die faktore

\footnotetext{
${ }^{19}$ Die metode van prosodiese analise berus op die tel van sillabes, wat deur Cross voorgestel is. Hanson eis dat hy dokumente wat so min as dertig jaar van mekaar geskryf is, met die metode kan onderskei. So vind hy 'n "meer barok"-styl in 'n sin of deel van 'n sin. Die barokkwaliteit hang dan af van die toename in een of twee sillabes in 'n kolon. In die lig van die beperkte kennis van Hebreeuse taal en literatuur kan so 'n werkswyse nie as wetenskaplik geldig aanvaar word nie.
} 
nêrens anders as in die apokalipse self vind nie. Rowland (1982) het bygedra om dié gevolgtrekking te maak. Sy werk is deur Collins (1984) opgevolg. Albei skrywers meen dit is nodig om verder as Hanson te gaan.

'n Rede vir verdere ondersoek was die ontdekking van apokaliptiese kenmerke in verskeie Qumranrolle. Die gevolgtrekking is dat die apokaliptiese mentaliteit deel van 'n algemene Joodse lewensuitkyk mag gevorm het. Gruenwald (1980:29) meen dat die oorsprong van apokaliptiek nie in die eerste plek by profesie nie, maar by Joodse mistiek gesoek moet word. Gruenwald en Rowland stem saam dat apokaliptisisme eerder in die lig van die Joodse ervarings tydens die Seleukiede en Hasmonese periode geëvalueer moet word, as deur 'n direkte verbintenis met die kanon. Cook (1989:115) en Grabbe (1989:31) meen apokaliptisisme is die resultaat van 'n kombinasie van faktore: die eskatologiese belange en goddelike inspirasie van klassieke profesie, die mantiese wysheid van die siener, die passie om die ware betekenis van die Skrif te ken (gekoppel aan die idee dat alle beeldspraak ' $n$ verborge, misterieuse betekenis het), en die behoefte aan sekerheid in onseker tye (vgl ook Bartlett 1984:27).

Collins (1984:146) meen meer aandag behoort aan die diverse kulturele agtergronde waarin vroeë Judaïsme bestaan het, gegee te word. Hy vestig die aandag op die potensiële invloed van Babiloniese, Persiese, Egiptiese en Hellenistiese kulture op Judeërs se denke..$^{20}$ Juda se teologiese denke was in dié tyd vloeibaar, en daar is alle rede om te aanvaar dat ander kulture ' $n$ invloed op Joodse denke uitgeoefen het. ${ }^{21}$

Veral Persiese invloede speel moontlik 'n rol in apokaliptiese literatuur. Hier word gedink aan idees soos die periodisering van die geskiedenis, eskatologiese weë, die leer van die opstanding, en die onderskeid tussen bonatuurlike magte wat die goeie en die bose verteenwoordig (Rowland 1982:209; Collins 1984:25). Die verbintenisse is egter baie algemeen, en min kan daaruit afgelei word (Oswalt 1999:387).

Navorsers het ook begin besef dat dit nie moontlik is om 'n enkele sosiale agtergrond vir apokaliptiese literatuur te poneer nie. Die lewensuitkyk is nie noodwendig tipies van gemarginaliseerde groepe nie. Waar vroeër aan die Qumrangemeenskap as 'n enkele geïsoleerde sekte gedink is, besef geleerdes vandag dat die Qumranliteratuur eerder 'n literêre kruisseksie van

\footnotetext{
${ }^{20}$ Sommige wil die oorsprong van Joodse apokaliptiek eksklusief in buitelandse invloede soek. Hier word veral aan Iranese of Persiese invloede gedink. So 'n direkte beïnvloeding is, myns insiens, geensins bevredigend bewys nie, en hoogs onwaarskynlik. Feit is: Daniël het van talle verskillende strome gedrink, maar die invloede so geïntegreer dat sy werk uniek in die literatuurwêreld is (Davies 1985:68).

${ }^{21}$ Dit kan ook die rede wees hoekom mitologiese motiewe in literatuur uit dié periode gebruik is.
} 


\section{Konteks(te) waarbinne apokaliptiese geskrifte floreer het}

Joodse denke van die laat pre-Christelike era verteenwoordig. In dieselfde sin is apokaliptisisme 'n denkrigting van die Joodse samelewing as 'n geheel.

\subsection{Tweede-eeuse apokaliptiese literatuur}

In die tweede eeu vC oefen Hellenisme 'n groot invloed uit om die apokaliptiese beweging in Israel te stimuleer in die nuwe krisissituasie wat rondom die regering van Antiochus IV ontstaan. Hieruit ontstaan die geskrifte wat oorgelewer is as Daniël; Susanna; Bel en die draak; die Gebed van Asarja; Tobit; en die Brief van Jeremia.

Joodse apokaliptiek vertoon 'n duidelike polemiese karakter. Dit is 'n instrument vir doeleindes van propaganda om weerstand teen die helleniseringsbeleid van die Grieks-Siriese oorheersers aan te moedig, met hul kulturele en godsdienstige sinkretisme, maar ook teen die Joodse party wat bereid is om te kompromitteer. Daniël val in die laaste fase van die stryd om 'n suiwer Jahwisme in Israel, wat reeds in die priester-en-profeet Elia verwoord is (LaCocque 1988:124).

Die apokaliptiese wêreldbeeld verskil radikaal van die moderne mens se siening van die gang van die geskiedenis. Dit is in simboliese taal geskryf waarvan die betekenis soms ons te bowe gaan, met mitologiese beelde wat grotesk en bisar voorkom. Hoe kan die moderne mens sin daarvan maak? Bybelse teologie moet met die raaisels van antieke apokaliptiek stoei, "such as its sectarian myopia and its disparagement of mundane realities". Teologie doen dit met groot sorg dat die konkrete omstandighede wat aanleiding gegee het tot die simboliese univers, deeglik verstaan word (Hanson 1976:34).

\section{SINTESE}

Wat was die sosio-ekonomiese konteks(te) waarbinne apokaliptiese tekste vanaf $200 \mathrm{vC}$ tot $100 \mathrm{nC}$ ontstaan het? Verskeie antwoorde is deur navorsers gebied, dat die konteks(te) waarbinne apokaliptiek ontstaan het, binne die wysheidstradisie gesoek moet word; die gevolg is van 'n pessimistiese siening van geskiedenis wat geen hoop vir 'n toekoms bied nie; 'n kontinuering en diskontinuering van profesie of profetiese eskatologie is; 'n herinstelling van mite binne die hoofstroom Joodse godsdiens is; die gevolg van 'n oriëntering aan die simboliese universum wat op 'n bonatuurlike wêreld geskoei is; en as die sosiologiese matriks van vervreemding. Vandag stem baie navorsers saam dat dit nie moontlik is om veralgemenend te spekuleer oor 'n sosiohistoriese konteks vir apokaliptiek nie maar dat die oorsprong daarvan afgestem moet word in terme van elke apokalips op sigself, in die lig van Joodse belewenisse tydens die Seleukidiese en Hasmonese periodes. 
Een van die gevare is dat die moderne mens die mitologie wat ten grondslag van die apokaliptiese beelde lê, se ankertoue loskap. Dan dryf die interpretasie sonder 'n seil in gevaarwaters. In die woorde van Reinhold Niebuhr (aangehaal in Russell 1994:57): mitologie moet altyd ernstig opgeneem word, maar nooit letterlik nie. 'n Letterlike interpretasie weier om die openbaring apart van sy modus van openbaring te sien. Terselfdertyd ontwyk dit die verantwoordelikheid om dit te probeer verstaan in terme van vandag se kultuur. So 'n interpretasie eindig maklik in obskurantisme of bygelowigheid.

'n Belangrike kenmerk by apokaliptiese skrywers is die verandering in fokus van die natuurlike na die bonatuurlike, van aardse regerings na 'n goddelike regering. So 'n siening is diep beïnvloed deur die tyd waarin die apokaliptici geleef het. Hul geskrifte is protes- of weerstandsliteratuur in terme van 'n politieke tirannie of in terme van 'n bose wêreld wat hulle omring (Russell 1994:59).

Apokaliptici het in hul blik op die bonatuurlike wêreld iets gesien wat alles te bowe gaan wat hier op aarde gebeur. Hulle was daarna nuwe mense, wat dinge sien wat hul verdrukker nie kon sien nie. Hulle het 'n wêreld beleef wat die mens wat slegs die natuurlike wêreld ken, nie kan visualiseer nie. Dit is nie 'n negatiewe soort ontvlugting nie, maar 'n positiewe ervaring van goddelike versekering wat tot 'n morele besluit lei, om protesoptrede en weerstand te vervang met geloof in die beloftes van God, om angs oor die toekoms te verruil vir die versekering dat God in menslike gebeure regeer. Met behulp van die boek kan gelowiges hul lot sien, nie in die lig van politieke en ekonomiese gebeure wat hul toekoms bepaal nie, maar van die einde. Tyd word nou gesien in die lig van die ewigheid, die natuurlike in die lig van die bonatuurlike, hierdie eeu in die lig van die eeu wat kom.

\section{Literatuurverwysings}

Aune, D E 1983. Prophecy in early Christianity and the ancient Mediterranean world. Grand Rapids, Ml: Eerdmans.

Baldwin, J G 1978. Daniel. Leicester: Inter-Varsity Press. (Tyndale Old Testament Commentaries.)

Barker, M 1977. Slippery words III: Apocalyptic. Expository Times 89, 325.

Bartlett, A L 1984. Jesaja 24-27: 'n Verkennende studie. Proponentestudie, Universiteit van Pretoria.

Brockhaus, R s.a. Door het vuur: Beschouwing over het boek Daniël, vertaald door J Tiesema. Den Haag: J N Voorhoeve.

Brueggemann, W 1983. Trajectories in Old Testament literature and the sociology of ancient Israel, in Gottwald, N K (ed), rev ed. The Bible and liberation: Political and social hermeneutics, 307-335. Maryknoll, NY: Orbis. 
Brueggemann, W 1997. Theology of the Old Testament: Testimony, dispute, advocacy. Minneappolis, MN: Fortress.

Burden, J J 1987. Die boek Daniël, Deel 3, in Burden, J J \& Prinsloo, W S (red), Tweegesprek met God: Die literatuur van die Ou Testament, 195-220. Kaapstad: Tafelberg.

Cantor, N F 1994. A modern history of the Jews. New York: P Lang.

Carroll, R P 1979. When prophecy failed: Cognitive dissonance in the prophetic traditions of the Old Testament. London: SCM.

Charles, R H 1963. Eschatology: The doctrine of a future life in Israel, Judaism and Christianity: A critical history. New York: Schocken.

Collins, J J 1977. The apocalyptic vision of the book of Daniel. Missoula, MT: Scholars Press. (Harvard Semitic Monographs 16.)

Collins, J J 1984. The apocalyptic imagination: An introduction to the Jewish matrix of Christianity. New York: Crossroad.

Collins, J J 2003. From prophecy to apocalypoticism: The expectation of the end, in McGinn, B J, Collins, J J \& Stein, S J, The continuum history of apocalypticism, 64-88. New York: Continuum.

Collins, J J 2004. Introduction to the Hebrew Bible. Minneapolis, MN: Fortress.

Cook, E M 1989. In the plain of the wall (Dan 3:1). JBL 108, 115-116.

Cross, F M 1966. Divine warrior in Israel's early cult, in Altmann, A (ed), Biblical motifs: Origins and transformations, 11-30. Cambridge: Harvard University Press.

Cross, F M 1973. Canaanite myth and Hebrew epic: Essays in the history of religion of Israel. Cambridge: Harvard University Press.

Davies, P R 1985. Daniel. Sheffield: JSOT. (Old Testament Guides.)

DiTomassa, $L$ 2005. The Book of Daniel and the apocryphal Daniel literature. Leiden: Brill. (Studia in Veteris Testamenti Pseudepigraphi 20.)

Enslin, M S 1971. The apocalyptic literature, in Layman, C M (ed), The interpreter's one-volume commentary on the Bible: Including all the books of the Old and New Testament and the Apocrypha, together with forty-three general articles, 1106-1109. London: Collins.

Grabbe, $L$ L 1989. The social setting of early Jewish apocalypticism. JSPE 4, 27-47. Gruenwald, I 1980. Apocalyptic and merkavah mysticism. Leiden: Brill. (AGJU 14.)

Hanson, P D 1976. Apocalypticism, in Interpreter's Dictionary of the Bible Suppl, 2834. Nashville, TN: Abingdon.

Hanson, P D 1979. The dawn of apocalyptic: The historical and sociological roots of Jewish apocalyptic eschatology, rev ed. Philadelphia, PA: Fortress.

Hanson, P D 1995. Isaiah 40-66. Louisville, KY: John Knox.

Joubert, W H 1979. Power and responsibility in the Book of Daniel. DTh Dissertation, University of South Africa.

Koch, K 1972. The rediscovery of apocalypse. London: SCM. (Studies in Biblical Theology, 2nd series, 22.)

Koch, K 1987. Is Daniel also among the prophets? in Mays, J L \& Achtemeier, P J, Interpreting the prophets, 237-248. Philadelphia, PA: Fortress.

Kratz, R G 2002. The visions of Daniel, in Collins, J J \& Flint, P W, The Book of Daniel: Composition and reception, Vol 1, 91-113. Boston, MA: Brill.

LaCocque, A 1988. Daniel and his time: Studies of personalities of the Old Testament. Columbia, SC: University of South Carolina Press. 
LaCocque, A 2002. Allusions to creation in Daniel 7, in Collins, J J \& Flint, P W, The Book of Daniel: Composition and reception, Vol 1, 114-131. Boston, MA: Brill.

Le Roux, J H 1988. Eschatology and the prophets (A survey of the research). OTE 1, $1-26$.

Millar, W R 1976. Isaiah 24-27 and the origin of apocalyptic. Missoula, MT: Sholars Press. (HSM 11.)

Moltmann, J 1967. Theology of hope, tr by J W Leitch. New York: Harper \& Row.

Morris, L 1972. Apocalyptic. Grand Rapids, MI: Eerdmans.

Oswalt, J N 1999. Recent studies in Old Testament apocalyptic, in Baker, D W \& Arnold, B T (eds), The face of Old Testament studies: A survey of contemporary approaches, 369-390. Grand Rapids, MI: Baker Books.

Porteous, N 1979. Daniel, 2nd rev ed. London: SCM. (Old Testament Library.)

Rowland, C 1982. The open heaven: A study of apocalyptic in Judaism and early Christianity. New York: Crossroad.

Russell, D S 1994. Prophecy and the apocalyptic dream: Protest and promise. Peabody, MA: Hendrickson.

Schmithals, W 1975. The apocalyptic movement: Introduction and interpretation, tr by J W Steely. Nashville, TN: Abingdon.

Soggin, J A 1984. A history of Israel: From the beginnings to the Bar Kochba revolt, $A D$ 135. London: SCM.

Stahl, R 1994. Von Weltengagement zu Weltüberwindung: Theologische Positionen im Danielbuch. Kampen: Kok Pharos. (Contributions to Biblical Exegesis \& Theology 4.)

Venter, P M 1997. Daniel and Enoch: Two different reactions. HTS 53(1\&2), 68-91.

Verhoef, P A 1993. Profete en profesie. Kaapstad: Lux Verbi.

Von der Osten-Sacken, P 1969. Die Apokalyptik in ihrem Verhältnis zu Prophetie und Weisheit. Münich: Christian Kaiser. (Theologische Existenz heute 157.)

Von Rad, G 1965. Old Testament Theology, Vol 2: The theology of Israel's prophetic tradition, tr by D M G Stalker. London: SCM.

Vorster, W S 1986. Tekste met 'n apokaliptiese perspektief, in Deist, F \& Vorster, W (red), Woorde wat ver kom: Die literatuur van die Ou Testament, Deel 1, 158176. Kaapstad: Tafelberg. 